UDK 378.14

DOI 10.22363/2312-8631-2017-14-1-42-48

\title{
PYRAMID METHOD OF DISTANCE LEARNING IN HIGER EDUCATION
}

\author{
D.V. Senashenko ${ }^{1}$, M.D. Senashenko ${ }^{2}$ \\ ${ }^{1}$ LLC «Avaya CIS» \\ Kosmodamianskaja naberezhnaja, 52/3, Moscow, Russia, 115253 \\ ${ }^{2}$ National research university «Higher School of Economics» \\ Myasnitskaya str., 20, Moscow, Russia
}

The article deals with modern methods of distance learning in the corporate sector. On the specifics of the application of the described methods is their classification and be subject to review their specific differences based on the features and applications of these techniques given the characteristics of the organization of teaching in higher education, a conclusion about their preferred sides, which can be used in distance education. Later in the article, taking into account the above factors, it is proposed an innovative method of formation of educational programs. In view of the similarity of the rendered appearance of the pyramids, this technique proposed name "pyramid". Offered by the authors, this technique is best synthesis of the best features of the previously described in the article for the online teaching methods. In the future, we are given a detailed description and conducted a preliminary analysis of the applicability of this technique to the training process in the Russian Federation. The analysis describes the eight alleged authors of distance education problems of high school that this method can help to solve.

Key words: distance learning, online education, online university, cross-border training, online courses

\section{Introduction}

Distance learning in the corporate sector is actively developing through more than two decades [1]. The explosive growth of companies focused on software development urges to develop various forms of internal training is not tied to the physical hardware. Such training is characterized by a complete lack of any kind of equipment, which is usually built around learning in corporations. Moreover, the globalization of economy requires the creation of far-flung jobs, which in turn causes the need for a large number of staff travel for training purposes. Thus, the development of distance learning in the corporate sector is aimed at not only the constant re-training staff in new technologies, but also a simultaneous reduction in the cost of moving employees to training centers.

In the past, during quite long period, enough variety of both classic and innovative distance learning methodologies has been tested. Clearly, the time has come to examine these techniques in order to use the best of them for the technological support of distance learning in higher education.

Distance learning in international corporations is divided into two types, which are stated into different components: internal training, which aims to re-training of personnel, or training of new employees, and external training, what can be so-called online 
universities and online courses, which are the actual business of the company, designed to provide training and external audiences. There is a relevance of links between various types of learning different training techniques. However, all types can be useful if to consider the distance in learning in higher education is taking into account its specific features.

\section{Online Universities}

The history of the development of online universities can be described in sufficient details in [2]. In Russia, this type of training was not widespread until recently. The catalyst for the development, as it would have sounded strange, were sanctions and low oil prices. The largest consumers of high-tech solutions in the country are the public sector, the banking sector and a number of so-called natural monopolies. Reduction of "petrodollars" flow required freeze or stop of the high-tech projects and, as a result, caused the dismissal or partial unemployment of highly skilled workers. In terms of labor market, data reduction specialists prefer to spend the released time to invest in their education, which has contributed to the active development of online universities in our country. So, below are developing dynamically following online platforms: netology.ru, skillbox.ru, synergy.ru, msk.itstep.org, coursera.org, geekbrains.ru, shpb.ru, e-legion.ru, specialist.ru. Russia is far from 27 foreign on-line university courses [3], but the application made is very serious.

In parallel, online educational platform based on Russian educational institutions are developing. For example, an online university "Open education" [4]. Building a model of learning in these areas are similar to those in the business areas mentioned above. Therefore, their selection somehow seems inappropriate.

A learning process in the online universities, mentioned before, is built on two main principles. Without the participation of "live" teacher and with the participation thereof. For example, e-legion.ru offers training video screening test. Video content can be viewed to a student any number of times and to take the test as many times. It is assumed that the student in the design sufficiently motivated to acquire knowledge, so there are no barrier mechanisms for the development of the course and final test of knowledge.

Another principle of learning offers on-line University skillbox.ru. Each class has video teaching materials and homework. Then "live" instructor checks homework and admission to the next class can be given to the only one who has successfully completed this task. Videos for each class can also be viewed an unlimited number of times. This offers additional materials for study and provides links to related resources at the Internet. Homework gives up as many times as required for a thorough understanding the subject. Criteria for passing the course by the student is the full development, and, in contrast to the first method, this system guarantes a sufficiently large amount of knowledge, of course, if the student maintains all the "burdens" of training and successfully completes this course.

Both of the above on-line universities put its top priority improving their own financial status. However, the achievement of goals are different. The first method is aimed at achieving the quantitative indicators of pupils, while the second method - on the quality indicators that are apparently supposed to be in the future affect the image of the organization and this type of training, which ultimately should obviously lead to the original problem - an increase in sales realized educational programs. 


\section{Pyramid technique of remote training}

Pyramid technique of distance learning in the corporate sector is used to get the guaranteed trained expert on a certain topic. The main components of this technique are shown in Figure 1.

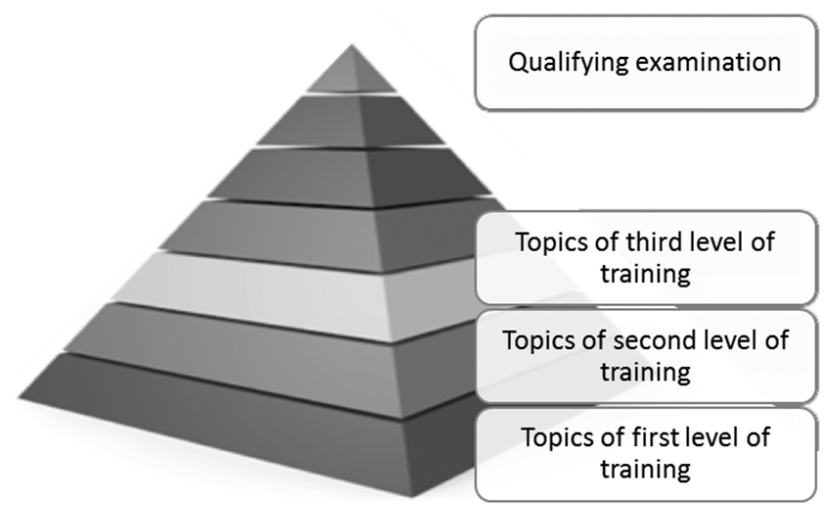

Figure 1. The pyramid of knowledge

This pyramid is a list of training levels in the framework of our educational program and is the basis of a structure that can be changed in the transition from one educational program to another. At the bottom are placed the primary theme, let us call them the theme of the first level of education. At the second level - the theme of the second level of training, on the third - the third and so on. On top of the pyramid is actually an examination in a given educational program, which is a confirmation of its development. The student can pass each level threads in any order. At the same time, any topic appears as a separate online course, ending on a separate mini online exam when the student must answer correctly a certain percentage of questions. Questions for each topic are prepared in an excess (double) amount. Only some of the questions are repeated in the case of repetition online exam.

The development of the second-level threads can be started only after passing the online exam on the first level, which is the basis of the second-level topics. Each topic at any level the student can pass an unlimited number of times for as long as he will not be able to pass the online exam in the subject.

Total student to the top of the pyramid can only come if it has successfully passed all of the mini-online examinations in all subjects contained in the pyramid. The final exam is usually held in person, checking passports, independent testing centers, offices which are located around the world. Vue [5] and Prometric [6] - Known testing centers.

\section{Features of the pyramid technique in high school}

The specificity of the learning process at any educational institution higher education is quite complex and branched structure of successive educational programs. In contrast to on-line universities, offer courses are usually not associated with each other and offered separately. This training scheme is intended primarily as a means of training, and is usually conducted in a free and non-working time. Allow this dialectical contradiction can help method of training - "knowledge pyramid". 
Another feature of learning in higher education is a requirement of the guaranteed minimum amount of knowledge in a certain discipline, and therefore its control. Typically, online universities are not concerned about the quality control of the knowledge gained since it is assumed that the student is sufficiently motivated for their high quality mastering, because usually he pays the amount of information provided. To solve this problem can be full-time remote method passing tests, homework, and exams.

\section{Possible model of online learning in higher education}

Decision of the foregoing problems of distance learning in higher education may become the next model of online learning: in the beginning of the course or semester, the student is given training scheme based on the construction of the "pyramid of knowledge." At the base of the pyramid are the primary topics in each discipline. At the top of the pyramid is actually an indicator of the semester or course completion. In the penultimate floor of the pyramid are the examinations for each discipline, depending on the importance of discipline exam can be a full-time or on-line. Intramural exam, test or colloquium may be held either in person or on the premises of educational institutions, and through video-conference communication system described in [7].

The entire theoretical part is given through videos or links to additional materials for self-study. A student can study them at any time convenient to him. Homework primary and intermediate inspections may be carried out through on-line tests. In the following stages (floors of the pyramid) homework and verification work has already tested an employee of the educational institution internally or through conferencing system. Homework can be submitted through the educational portal for conducting transparent reporting, or via e-mail, web chat, or other applications designed for the organization of collective work.

In addition, this technique provides for the active involvement of the teaching staff of higher education in the learning process, which, in turn, avoids the problems of organization of teaching, described in [8]. At the same time the possibility of the proposed method are that e-learning methods routine part of the training is transferred. Teaching the structure involved is to perform the intellectual component of the educational process.

The problems of cross-border education is also solved by this technique effectively. At the stage of admission of students to study full-time can pass some kind of student identity verification by an authorized person directly to the student's country of residence. As a result, the student creates a profile with a photo and the verified data submitted by authorized person personally. In the course of completing the course with the occasional use of systems of video-conference connection instructor may consult with a verified profile. Objectivity personal communication system through video conference due to the high resolution is that the possibility of fraud by replacing the student to another person is not possible. Taking into account the frequent participation of the student in person and remote examinations and other screening measures for a long enough period, the possibility of manipulating the knowledge test are minimal. If at the initial stage of the student still has the ability to carry out fraud and to issue or whose knowledge of their own, then passing to a higher level of training full-time-remote verification becoming regular and anyone previously realized, a forgery anyway become apparent. 
Similarly, the problem can be solved by distance learning within the country. The student when applying for training can pass identity verification procedure such as appearing in person at the central or regional office, or, as a variant, preparing documents with the notary. Exams or other full-time-remote sessions can be organized in the premises of the regional offices of educational institutions using videoconference equipment with high resolution.

Thus, the pyramidal method of distance learning organization can solve the following problems:

1. Develop training methodically reasonable structure, and, therefore, provide a logical sequence of passing educational programs in distance learning.

2. To ensure the level of knowledge of students at the expense of full-time instructor knowledge test.

3. To provide a clear visualization of the level of knowledge of students, due to the visibility of the "pyramid of knowledge."

4. To create conditions for the active involvement of the teaching staff in the learning process in the creative level.

5. To send a routine component of training in on-line learning system.

6. To contribute to improving the efficiency of cross-border education.

7. To encourage the development of quality distance education within the country.

8. At the same time the educational process with the use of distance learning can be carried out by educational institutions for full-time, part-time (evening), correspondence forms of education, in the form of external or a combination thereof.

During the learning process mediated by purposeful or not fully mediated by the interaction of students and teacher is independent of location and time allocation based on pedagogically organized distance learning technologies including case technology, Internet technology, telecommunications technology, or a combination thereof.

\section{REFERENCES}

[1] Distancionnoe obuchenie [Distance education]. URL: https://en.wikipedia.org/wiki/Distance_ education

[2] Balatsky E.V. Novye trendy v razvitii universitetskogo sektora [New Trends in the Development of the University Sector]. Mir Rossii [World of Russia]. 2015. Vol. 24. No. 4. Pp. 72-98.

[3] 27+ resursov dlja onlajn-obuchenija [27+ resources for online education]. URL: https://habrahabr. $\mathrm{ru} / \mathrm{post} / 156241 /$

[4] Otkrytoe obrazovanie [Open Education]. URL: https://openedu.ru

[5] Pearson Vue. URL: https://home.pearsonvue.com

[6] Prometric. URL: https://www.prometric.com/en-us/pages/home.aspx

[7] Senashenko D.V., Senashenko M.A. O primenenii sistem videokonferencsvjazi v vysshej shkole dlja distancionnogo obuchenija [On using video conference systems in higher school for distance learning]. Vestnik Rossijskogo universiteta druzhby narodov. Serija «Informatizacija obrazovanija» [Bulletin of the Russian university of friendship of the people. Education Informatization series]. 2015. No. 4. Pp. 54-58.

[8] Tre'yakov V.S., Larionova V.A. Otkrytye onlajn-kursy kak instrument modernizacii obrazovatel'noj dejatel'nosti $v$ vuze [Open online courses as a tool for modernization of educational process in Universities]. Vysshee obrazovanie v Rossii [Your education in Russia]. 2016. No. 7 (203). Pp. 5566.

(C) Senashenko D.V., Senashenko M.D., 2017 
Article history:

Received: 28 September 2016

Accepted: 24 October 2016

For citation:

Senashenko D.V., Senashenko M.D. Pyramid method of distance learning in higer education // RUDN Journal of Informatization Education. 2017. 14 (1). 42-48.

\title{
Bio Note:
}

Senashenko Dmitry Vasilyevich, leading engineer, expert in telecommunications of firm of Avaya CIS limited liability company.

Contact information: e-mail: dsenashenko@avaya.com.

Senashenko Mariya Dmitrievna, student of National research university "Higher School of Economics".

Contact information: msenashenko@avaya.com.

\section{О ПИРАМИДАЛЬНОЙ МЕТОДИКЕ ДИСТАНЦИОННОГО ОБУЧЕНИЯ В ВЫСШЕЙ ШКОЛЕ}

\author{
Д.В. Сенашенко ${ }^{1}$, М.Д. Сенашенко ${ }^{2}$ \\ ${ }^{1}$ ООО «Авайя СНГ» \\ Космодамианская набережная, 52/3, Москва, Россия, 115253 \\ ${ }^{2}$ Национальный исследовательский университет «Высшая школа экономики» \\ ул. Мясницкая, 20, Москва, Россия
}

\begin{abstract}
В статье рассматриваются современные методики дистанционного обучения в корпоративном секторе. По специфике применения описанных методик делается их классификация и проводится рассмотрение их специфических отличий. Основываясь на особенностях применений данных методик и учитывая особенности организации обучения в высшей школе, авторы делают вывод об их предпочтительных сторонах, которые могут быть использованы в дистанционном образовании. Далее в статье с учетом вышеизложенных факторов описывается инновационная методика формирования образовательных программ. В связи со схожестью визуализированного внешнего вида с пирамидами для данной методики вводится название «пирамидальная». Предлагаемая авторами методика является синтезом лучших особенностей, описанных ранее в статье методик для онлайн-обучения. В дальнейшем дается ее подробное описание и проводится предварительный анализ применимости данной методики к процессу обучения в Российской Федерации. В ходе анализа дается описание восьми предполагаемых авторами проблем дистанционного образования высшей школы, которые может помочь решить данная методика.
\end{abstract}

Ключевые слова: дистанционное образование, интернет-образование, онлайн-университеты, трансграничное обучение, онлайн-курсы

\section{История статьи:}

Дата поступления в редакцию: 28 сентября 2016

Дата принятия к печати: 24 октября 2016 


\section{Для цитирования:}

Сенашенко Д.В., Сенашенко М.Д. О пирамидальной методике дистанционного обучения в высшей школе // Вестник Российского университета дружбы народов. Серия «Информатизация образования». 2017. Т. 14. № 1. С. 42-48.

Сведения об авторах:

Сенашенко Дмитрий Васильевич, ведущий инженер, эксперт по телекоммуникациям фирмы общества с ограниченной ответственностью «Авайя СНГ».

Контактная информация: e-mail: dsenashenko@avaya.com.

Сенашенко Мария Дмитриевна, студентка Национально-исследовательского университета «Высшая школа экономики».

Контактная информация: e-mail: msenashenko@avaya.com. 